\title{
Predisposisi Partisipasi Masyarakat dalam Perencanaan Kampung Wisata (Studi Kasus Kampung Wisata Santan)
}

\author{
D O I: $10.18196 /$ agr.2124
}

\begin{abstract}
This study aimed to analyze predisposition (readiness), especially understanding and attitudes towards the tourist village program and to analyze community participation in the declaration and plan of participation in the program tourist village. The experiment was conducted in the village (Kampung) Santan Village Guwosari, Pajangan Bantul. Respondents are determined by the census. The results showed general cognitive understanding people's understanding of the tourist village, the knowledge of the planning and launching of Kampung Dusun Santan as Tourism is still largely lacking (only know a little bit). This is due to the constraints of socialization and domination of the village leaders in planning the tourist village less evenly involve villagers.
\end{abstract}

Once people get the socialization though still very limited, affective response was very positive and support the tourist village. They hoped that Kampung Santan be more advanced and increased economy. Public participation in the tourist village program showed improved symptoms, ranging from participation since the planning, at the time of the declaration and the time after the launching. Forms of participation can be seen from the amount of involvement of communities themselves and plan the most desirable programs. Tourism Village program were most interested in the community is the provision of infrastructure, because the program is expected to bring direct benefits to the community. It is recommended that the socialization and solidarity of citizens needs to be improved so that participation can be improved.

Keywords: predisposition, response, participation, tourist village.

\section{INTISARI}

Penelitian ini bertujuan untuk menganalisis predisposisi (kesiapan), terutama pemahaman dan sikap masyarakat terhadap program kampung wisata, serta menganalisis partisipasi masyarakat dalam pencanangan dan rencana partisipasi dalam program kampung wisata. Penelitian dilaksanakan di Dusun (Kampung) Santan, Desa Guwosari, Pajangan Kabupaten Bantul. Responden ditentukan secara sensus. Hasil penelitian menunjukkan, secara umum pemahaman kognitif masyarakat terhadap pengertian kampung wisata, pengetahuan akan perencanaan dan pencanangan Dusun Santan sebagai Kampung Wisata masih kurang (hanya tahu sedikit). Hal ini disebabkan terdapatnya kendala sosialisasi dan dominasi para tokoh kampung dalam perencanaan kampung wisata yang kurang melibatkan warga kampung secara merata. Setelah masyarakat mendapatkan sosialisasi meskipun masih sangat terbatas, respon afektifnya sangat positif dan mendukung program kampung wisata. Masyarakat berharap agar Kampung Santan bisa lebih maju dan meningkat perekonomiannya. Partisipasi masyarakat dalam program kampung 
wisata menunjukkan gejala yang meningkat, mulai dari partisipasi dalam perencanaan, pada saat pencanangan, dan pada saat pasca pencanangan. Program Kampung Wisata yang paling diminati masyarakat adalah penyediaan sarana prasarana, karena program ini diharapkan mendatangkan keuntungan langsung pada masyarakat. Pemerataan sosialisasi dan kekompakan warga perlu diupayakan agar partisipasi dapat ditingkatkan.

Kata kunci: predisposisi, respon, partisipasi, kampung wisata.

\section{PENDAHULUAN}

Dusun Santan, merupakan salah satu pedusunan yang terletak di pusat Desa Guwosari, Kecamatan Pajangan, Kabupaten Bantul, Propinsi DIY; yang berjarak kurang lebih $6 \mathrm{~km}$ dari pusat kabupaten dan sekitar $25 \mathrm{~km}$ dari pusat propinsi DIY. Dusun dengan luas wilayah sekitar 14, 2115 ha, terdiri atas tanah pekarangan (10,1960 ha), tanah tegalan $(10,905)$, tanah sawah $(2,2115$ ha) dan tanah wakaf $(0,7135$ ha); berbatasan dengan Dusun Karangber di sebelah utara, Dusun Wijirejo di sebelah selatan, Dusun Kalakijo di sebelah barat dan Dusun Gilangharjo di sebelah timur.

Penduduk Dusun Santan berjumlah 516 jiwa, yang terdiri atas 270 orang laki-laki dan 246 orang perempuan; terbagi dalam $138 \mathrm{KK}$, yang tersebar di 4 (empat) RT. Pendidikan masyarakat di Dusun Santan relatif bagus, pada tahun 2013 terdapat 192 orang lulusan SD, 87 orang SMP, 132 orang SMA, 22 orang PT dan 83 orang tidak atau belum tamat SD. Mata pencaharian penduduk terbanyak petani, disusul buruh dan wiraswasta. Jenis ternak yang dominan dipelihara masyarakat Dusun Santan, antara lain sapi (11 ekor), kambing (42 ekor) dan ayam buras (sumber: Kepala Dusun Santan).

Kerajinan tempurung kelapa, merupakan salah satu usaha kerajinan yang saat ini dikembangkan masyarakat di Kampung Santan. Bermula dari satu rumah tangga yang merintis usaha kerajinan tempurung pada tahun 1992, sekarang terdapat 10 rumah tangga yang mengandalkan mata pencahariannya dari kerajinan tempurung kelapa (bathok). Dimulai dari perdagangan yang hanya bersifat lokal, pada tahun 1995 salah satu pengrajin, yaitu UKM Cumplung Aji, melakukan terobosan ekspor ke beberapa negara yaitu Jepang, TimurTengah, Perancis dan Malaysia, meskipun masih menggunakan jasa trader internasional.

Banyaknya pembeli (buyer) dari dalam maupun dari luar negeri yang datang langsung ke Dusun Santan untuk membeli produk kerajinan tempurung telah menjadikan Kampung Santan terlihat ramai. Ramainya orang yang datang ini telah memancing kesadaran warga untuk memanfaatkan monentum kunjungan tamu dengan menyediakan beberapa fasilitas seperti warung makan, penginapan dan fasilitas lain. Kondisi ini menggugah keinginan warga untuk menjadikan Dusun Santan sebagai Kampung Wisata berbasis kerajinan tempurung. Bertepatan dengan kunjungan Bapak Fadel Muhammad (Menteri Perikanan dan Kelautan tahun 2010) muncullah gagasan untuk mensosialisasikan Dusun Santan sebagai Kampung Wisata. Pencanangan Kampung Wisata (soft lounching) baru dilakukan pada 29 Mei 2011 dengan memanfaatkan media internet oleh Pemda Kabupaten Bantul (Dinas Pariwisata).

Perbincangan tentang kampung wisata melanda seluruh elemen masyarakat baik di Dusun Santan, dusun sekitar bahkan meluas lewat media masa. Kampung Wisata Santan mendapat respon yang sangat beragam. Hal ini terlihat jelas adanya perbedaan partisipasi masyarakat mulai dari pencanangan sampai pasca pencanangan sebagai Kampung Wisata. Apakah variasi partisipasi ini terjadi karena perbedaan pemahaman (persepsi) dan sikap berbagai elemen masyarakat tentang Kampung Wisata? Secara teoritis pemahaman, persepsi dan sikap merupakan predisposisi seseorang sebelum melakukan tindakan partisipasi. Perbedaan pemahaman dan sikap ini akan menimbulkan perbedaan perilaku (partisipasi) masyarakat dalam merespon gagasan pengembangan Kampung Wisata. Tidak jarang perbedaan ini menimbulkan gagalnya komunikasi sosial terutama dalam pengelolaan sehingga merugikan pengembangan Kampung Wisata. Oleh karena itu, kajian tentang predisisposisi atau kesiapan masyarakat menjadi penting dalam merencanakan Kampung Wisata.

Penelitian ini bertujuan untuk menganalisis predisposisi (kesiapan) terutama pemahaman dan sikap masyarakat terhadap program kampung wisata serta menganalisis partisipasi masyarakat dalam pencanangan dan perencanaan program kampung wisata. Jika gambaran predisposisi masyarakat dapat diketahui baik menyangkut pemahaman, persepsi dan sikap; maka perilaku masyarakat, dalam hal ini partisipasi masyarakat, dapat diarahkan pada tujuan program Kampung Wisata dengan cara memodifikasi berbagai faktor yang masih kurang dipahami atau dipersepsi dan disikapi secara negatif oleh masyarakat. Jika perilaku masyarakat dapat 
diarahkan, maka perencanaan kampung wisata akan menjadi lebih mudah untuk mencapai tujuan yang diharapkan. Meskipun penelitian ini merupakan studi kasus, namun hasilnya diharapkan dapat menjadi referensi pengembangan kampung atau desa wisata, mengingat di Kabupaten Bantul saja terdapat sekitar 26 desa wisata dengan tingkat perkembangan yang sangat bervariasi. Secara keilmuan hasil penelitian diharapkan ini akan memperkaya wacana dan ilmu pengetahuan, khususnya tentang perencanaan dan manajemen pariwisata

Pedesaan atau kampung memiliki peluang yang besar jika dikembangkan menjadi obyek wisata, karena menjanjikan brand image yang berbeda. Dimasa yang akan datang branding wisata akan lebih kompleks, setelah branding tempat menjadi mudah tergantikan dan sulit dibedakan (Pike, 2005). Pengembangan wisata pedesaan (rural tourism) sudah sejak lama menjadi topik kajian, termasuk di Amerika (Gartner, 2004)

Desa wisata adalah suatu wilayah yang menawarkan suasana keaslian pedesaan, baik dari segi sosial budaya, adat istiadat, arsitektur tradisional, serta mempunyai potensi kerajinan yang dapat dikembangkan menjadi sebuah tujuan pariwisata. Desa wisata merupakan pengembangan suatu wilayah dengan memanfaatkan unsur-unsur yang ada dalam masyarakat desa yang berfungsi sebagai atribut produk wisata, menjadi suatu rangkaian aktivitas pariwisata yang terpadu dan memiliki tema. Di dalam desa tersebut juga mampu menyediakan dan memenuhi serangkaian kebutuhan suatu perjalanan wisata, baik dari aspek daya tarik maupun berbagai fasilitas pendukungnya (Nugroho, 2011)

Untuk menjadi tujuan wisata dan dapat menarik untuk dikunjungi oleh wisatawan, suatu daerah harus memiliki 3 syarat. Pertama, suatu daerah harus mempunyai "something to see", artinya di tempat tersebut harus ada objek wisata dan atraksi wisata yang berbeda dengan yang dimiliki daerah lain, yang menjadi daya tarik khusus. Kedua, di daerah tersebut harus tersedia "something to do", artinya di samping banyak yang dapat dilihat, harus pula disediakan fasilitas rekreasi yang dapat membuat wisatawan betah tinggal lebih lama di tempat itu. Ketiga, di daerah tersebut harus ada "something to buy”, artinya di tempat itu harus ada fasilitas untuk dapat berbelanja, terutama souvenir kerajinan

Suatu daerah bisa menjadi objek pariwisata karena daerah tersebut mempunyai atraksi wisata, di mana dalam atraksi tersebut mempunyai beberapa aspek historis, aspek nilai, aspek keaslian, dan aspek handicraft. Pasal 29 Bab IV Undang-Undang No. 9 Tahun 1990 Tentang Kepariwisataan menyebutkan bahwa kawasan pariwisata merupakan suatu usaha yang kegiatannya membangun atau mengelola kawasan dengan luas tertentu untuk memenuhi kebutuhan pariwisata.

Kampung wisata harus didesain mengarah pada sustainable tourism sehingga perlu direncanakan sebaikbaiknya dengan melibatkan masyarakat. Menurut Lansing dan De Vries (2007) kampung wisata adalah konsep pariwisata berkelanjutan (sustainable tourism). Konsep ini diklaim sebagai konsep baru yang mampu mengatasi persoalan pengembangan wisata secara konvensional. Ada tiga hal penting dalam konsep kampung wisata, pertama pemanfaatan sumber daya lingkungan secara optimal dengan menjaga proses-proses ekologi utama dan memelihara warisan alam serta biodiversitasnya; kedua menghargai aspek sosial budaya masyarakat asli dan wisatawan; dan ketiga dalam jangka panjang menjamin kemudahan penyediaan manfaat sosial ekonomi bagi masyarakat (Welford dan Yttrhus, 2004; Lansing dan De Vries, 2007). Wisata berbasis pedesaan sesuai dengan konsep community base tourism yang juga merupakan salah satu model sustainable tourism (Blackstok, 2005).

Tourism adalah kegiatan besar dan bersifat global, sehingga diperlukan perencanaan yang spesifik. Perencana harus mengumpulkan banyak pengalaman dalam pendekatan metode perencanaan. Penelitian yang berkelanjutan dan percobaan dibutuhkan khususnya untuk menentukan bentuk optimum dari pengembangan yang dilakukan (Inskeep, 1988). Perencanaan tourism juga bisa dilakukan dengan pendekatan 4 A yaitu : attractions, actors, actions dan atmospheres (Echtner, 2002).

Inskeep (1988) juga menyatakan bahwa komponen penting dalam proses perencanaan wisata antara lain: i) sajian dan aktivitas wisata; ii) fasilitas akomodasi dan pelayanan, fasilitas pendukung seperti biro tour $\&$ travel, rumah makan, fasilitas kesehatan, keamanan, pos, bank dan money changer, fasilitas transportasi, infrastruktur pendukung seperti penyediaan air, telekomunikasi dan sumber energi (daya listrik); iii) kelembagaan pemasaran, pendidikan dan pelatihan, kebijakan dan peraturan pemerintah, serta kebijakan dan bentuk investasi, baik pemerintah maupun swasta.

Dalam implementasi perencanaan model diperlukan monitoring dan evaluasi untuk perbaikan perencanaan. Evaluasi dapat dilakukan dengan studi kelayakan yang memuat analisis tentang masalah yang mungkin terjadi 
jika suatu perencanaan dijalankan dan kemungkinan untuk mengatasinya secara efektif. Menurut Warnell (1986) dalam Damanik \& Weber (2006), studi kelayakan dilakukan untuk mengevaluasi kondisi nyata suatu produk atau jasa, mengevaluasi peluang pengembangannya, mengevaluasi peluang penciptaan produk dan jasa baru dan mengeidentifikasi penyandang dana yang potensial untuk suatu proyek. Menurut Steck (1999) dalam Damanik \& Weber (2006), studi kelayakan kampung wisata dapat diarahkan untuk menjawab pertanyaan: tujuan apa dan kepentingan siapa yang harus dicapai dalam proyek dan pelaku kampung wisata? Kelayakan menunjuk pada kepatutan secara ekonomi, sosial, budaya dan teknologi? Apakah kondisi lingkungan, sosial dan budaya lokal benar-benar mampu mendukung pengembangan kampung wisata? Apakah kondisi dasar sosial, politik dan kelembagaan setempat cukup kuat sehingga memungkinkan keuntungan kampung wisata dapat digunakan atau dinikmati oleh kelompok sasaran?

Undang-undang No. 25 Tahun 2000 tentang Program Perencanaan Nasional Pariwisata mengamanatkan bahwa pariwisata diharapkan turut mempercepat pemulihan ekonomi nasional dan memulihkan citra Indonesia di dunia internasional. Namun, penugasan ini semakin sulit akibat terjadinya tragedi 11 September 2001 di Amerika Serikat dan ancaman terorisme. Subsektor pariwisata diharapkan dapat menggerakan ekonomi rakyat, karena dianggap sektor yang paling siap dari segi fasilitas, sarana dan prasarana dibandingkan dengan sektor usaha lainnya. Harapan ini dikembangkan dalam suatu strategi pemberdayaan masyarakat melalui pengembangan pariwisata yang berbasis kerakyatan atau community-based tourism development.

Prospek pariwisata ke depan memberikan peluang besar, terutama apabila menyimak angka-angka perkiraan jumlah wisatawan internasional (inbound tourism) berdasarkan perkiraan WTO yakni 1,046 milyar orang pada tahun 2010 dan 1,602 milyar orang pada tahun 2020, masing-masing 231 juta dan 438 juta orang berada di kawasan Asia Timur dan Pasifik. Angka ini mampu menciptakan pendapatan dunia sebesar USD 2 triliun pada tahun 2020. Berdasarkan angka perkiraan tersebut maka, para pelaku pariwisata Indonesia perlu melakukan perencanaan yang matang dan terarah untuk menangkap peluang tersebut. Diperlukan "re-positioning" pariwisata Indonesia mulai dari pembuatan produk pariwisata, investasi, promosi, jaringan pemasaran internasional, dan penyiapan sumber daya manusia yang berkualitas.
Disamping jumlah wisman yang makin meningkat, saat ini telah terjadi perubahan consumers-behaviour pattern atau pola konsumsi dari para wisatawan. Pergeseran ini terjadi dari wisata yang hanya bersantai (plesure), ke jenis wisata santai sambil menikmati produk atau kreasi budaya (culture) dan peninggalan sejarah (heritage) serta nature atau keindahan alam dari suatu daerah atau negara. Perubahan pola wisata ini perlu disikapi oleh masyarakat dengan berbagai strategi pengembangan produk pariwisata. Pemerintah daerah perlu melakukan perubahan skala prioritas kebijakan, sehingga peran masyarakat dan swasta lebih optimal.

Sejak bulan Juli 2000, Bank Dunia melontarkan gagasan menanggulangi masalah kemiskinan melalui sektor pariwisata yang kemudian dikenal dengan community-based tourism (CBT). Tiga kegiatan pariwisata yang dapat mendukung konsep CBT yakni adventure travel, cultural travel dan ecotourism. Yang perlu mendapatkan perhatian khusus dalam konsep CBT adalah wisatawan domestik (wisnus). Obyek-obyek wisata yang sering dan padat dikunjungi oleh wisnus akan memperoleh manfaat lebih besar. Makin banyak wisnus berkunjung, makin terkenal obyek wisata tersebut dan pada akhirnya merupakan promosi untuk menarik datangnya wisman (Santosa, 2002).

\section{METODE PENELITIAN}

Penelitian dilakukan di Kampung Santan Desa Guwosari Kecamatan Pajangan Kabupaten Bantul. Tahapan pertama dilakukan survei pendahuluan berdasarkan data atau informasi dasar. Studi ekspolarasi dilakukan untuk penentuan lokasi dan penentuan responden penelitian. Lokasi penelitian ditentukan secara sengaja dengan pertimbangan kampung tersebut akan dijadikan wilayah dampingan dalam Program Pemberdayaan Masyaraka oleh pihak UMY melalui Program Desa Mitra yang akan dilaksanakan mulai tahun 2013 - 2017.

Penelitian ini merupakan penelitian deskriptif ekploratif yang dilakukan dengan metode survei. Penelitian dilakukan secara sensus terhadap kepala keluarga dengan pertimbangan bahwa kepala keluarga masih memiliki peran sentral dalam menentukan tindakan anggota keluarganya baik menyangkut kepentingan individu maupun kepetingan sosial kemasyarakatan. Jumlah responden dalam penelitian ini adalah 137 orang, dengan sebaran 30 orang di RT 01, 35 
orang di RT 02, 35 orang di RT 03, dan 27 orang di RT 04. Pengambilan data primer dilakukan dengan wawancara (interview) menggunakan kuisioner atau panduan pertanyaan. Data primer yang diambil meliputi data tentang profil responden, pemahaman, sikap dan partisipasi responden terhadap program kampung wisata di lokasi penelitian. Pengukuran data kualitatif dilakukan dengan metode skor yang kemudian dianalisis dengan bantuan tabel silang dan distribusi frekuensi yang dianalisis secara deskriptif.

Untuk melakukan konfirmasi atas data yang telah dikumpulkan dan untuk memantapkan kesimpulan dilakukan diskusi terfokus (FGD). Hasil FGD akan menjadi dasar perencanaan program kampung wisata. Secara skematis tahapan dan kerangka berpikir penelitian dapat dilihat pada bagan berikut.

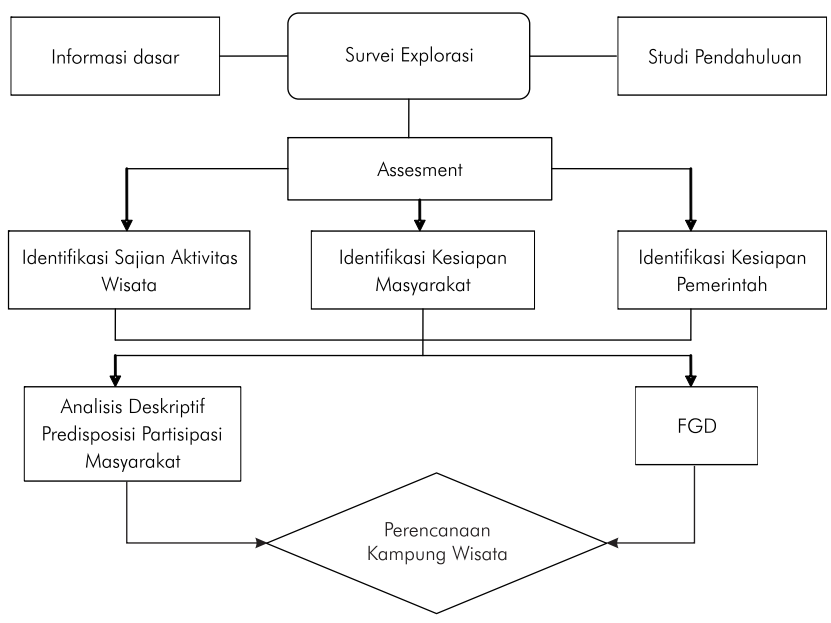

Gambar 1. Tahapan Penelitian dan Kerangka Berpikir Penelitian Predisposisi Partisipasi dalam Perencanaan Kampung Wisata

\section{HASIL DAN PEMBAHASAN}

Predisposisi partisipasi masyarakat terhadap pencanangan Kampung Wisata Dusun Santan dianalisis dari pengetahuan (pemahaman kognitif) dan sikap afektif; sedangkan partisipasi dilihat dari keikutsertaan masyarakat dalam perencanaan dan pelaksanaan pencanangan desa wisata, serta bentuk-bentuk program yang diminati dalam pengelolaan kampung wisata.

\section{PENGETAHUAN ATAU PEMAHAMAN (SIKAP KOGNITIF) MASYARAKAT TENTANG KAMPUNG WISATA}

Sikap kognitif berupa pengetahuan atau pemahaman masyarakat tentang Kampung Wisata Dusun Santan, secara umum masih kurang. Dari Tabel 1 dapat dicermati bahwa hampir separuh masyarakat hanya tahu sedikit bahkan tidak tahu sama sekali adanya musyawarah perencanaan Dusun Santan sebagai kampung wisata (45\%) maupun diresmikannya Kampung Wisata Santan pada tahun 2010 (50\%).

Berdasarkan Tabel 1 diketahui bahwa 52 persen masyarakat Dusun Santan hanya tahu sedikit mengenai apa yang dimaksud dengan kampung wisata, 29 persen tahu sebagian besar, dan 10 persen tidak tahu sama sekali; sedangkan yang tahu secara lengkap hanya 9 persen. Hal tersebut menandakan bahwa sebagian besar warga masih belum mengerti arti dari kampung wisata. Masyarakat yang tahu secara lengkap (13 orang) arti dari kampung wisata adalah para tokoh penggagas kampung wisata, baik tokoh formal maupu tokoh non formal. Jika dilihat lebih jauh lagi, dari 13 orang yang tahu secara mendetil arti kampung wisata, 9 orang diantaranya berdomisili di RT 03 yang menjadi pusat informasi dan kegiatan kampung wisata di Dusun Santan. Hal ini berarti, masyarakat yang tinggal di dekat pusat kegiatan dapat menangkap informasi lebih banyak dibandingkan dengan warga yang tinggal atau berdomisili dengan jarak lebih jauh.

Sebagian besar masyarakat (44\%) hanya tahu sedikit mengenai perencanaan pencanangan Kampung Wisata Dusun Santan; sedangkan yang mengetahui secara lengkap hanya 11 persen. Hal tersebut menggambarkan bahwa sebagian besar masyarakat Dusun Santan masih kurang informasi mengenai adanya musyawarah pencanangan Kampung Wisata Dusun Santan. Sebagian besar (8 orang) warga yang mengetahui secara lengkap mengenai adanya musyawarah pencanangan kampung wisata Santan berada di RT 03, yaitu para pengrajin bathok kelapa yang menjadi pelopor gagasan berdirinya kampung wisata. Pada awalnya, ide menjadikan Dusun Santan memang datang dari para pengrajin bathok kelapa yang kebanyakan tinggal di RT 03 Dusun Santan.

Sebanyak 36 persen masyarakat Dusun Santan mengetahui banyak tentang peresmian Dusun Santan sebagai kampung wisata, sedangkan 35 persen masyarakat mengetahui sedikit tentang adanya peresmian tersebut. Hal ini menunjukkan masih banyak masyarakat Dusun Santan yang memperoleh sedikit informasi tentang adanya peresmian Kampung Wisata Santan. Jumlah terbanyak warga yang mengetahui secara lengkap mengenai peresmian Kampung Wisata Santan berada di RT 03, yaitu 12 orang. Hal ini terjadi karena pusat 
TABEL I. DISTRIBUSI FREKUENSI PEROLEHAN SKOR BERDASARKAN SIKAP KOGNITIF

\begin{tabular}{|c|c|c|c|c|c|c|}
\hline \multirow{2}{*}{ No } & \multirow{2}{*}{ Komponen Sikap Kognitif } & \multirow{2}{*}{$\begin{array}{l}\text { Domisili } \\
\text { Responden }\end{array}$} & \multicolumn{4}{|c|}{ Perolehan Skor } \\
\hline & & & a & $b$ & c & $d$ \\
\hline \multirow[t]{6}{*}{1} & \multirow{4}{*}{ Pengetahuan tentang pengertian kampung wisata } & RT 01 & 5 & 12 & 12 & 1 \\
\hline & & RT 02 & 1 & 9 & 19 & 6 \\
\hline & & RT 03 & 7 & 13 & 22 & 3 \\
\hline & & RT 04 & 0 & 6 & 17 & 4 \\
\hline & Jumlah & & 13 & 40 & 70 & 14 \\
\hline & $\%$ & & 9 & 29 & 52 & 10 \\
\hline \multirow[t]{6}{*}{2} & \multirow{4}{*}{$\begin{array}{l}\text { Pengetahuan mengenai adanya rembug atau } \\
\text { musyawarah tentang perencanaan Dusun Santan } \\
\text { sebagai Kampung Wisata }\end{array}$} & RT 01 & 6 & 10 & 14 & 0 \\
\hline & & RT 02 & 1 & 16 & 13 & 5 \\
\hline & & RT 03 & 8 & 13 & 19 & 5 \\
\hline & & RT 04 & 0 & 8 & 14 & 5 \\
\hline & Jumlah & & 15 & 47 & 60 & 15 \\
\hline & $\%$ & & 11 & 34 & 44 & 11 \\
\hline \multirow[t]{6}{*}{3} & & RT 01 & 4 & 11 & 12 & 3 \\
\hline & Pengetahuan berkaitan dengan diresmikannya & RT 02 & 2 & 13 & 11 & 9 \\
\hline & Kampung Wisata Santan pada tahun 2010 & RT 03 & 12 & 16 & 14 & 3 \\
\hline & & RT 04 & 2 & 9 & 11 & 5 \\
\hline & Jumlah & & 20 & 49 & 48 & 20 \\
\hline & $\%$ & & 14,5 & 36 & 35 & 14,5 \\
\hline
\end{tabular}

Keterangan skor:

a. Tahu secara lengkap b. Tahu sebagian besar c. Tahu sedikit d. Tidah tahu sama sekali

TABEL 2. DISTRIBUSI FREKUENSI PEROLEHAN SKOR BERDASARKAN SIKAP AFEKTIF

\begin{tabular}{|c|c|c|c|c|c|c|}
\hline \multirow{2}{*}{ No } & \multirow{2}{*}{ Komponen Sikap Afektif } & \multirow{2}{*}{ Domisili } & \multicolumn{4}{|c|}{ Perolehan Skor } \\
\hline & & & $a$ & $\mathrm{~b}$ & c & $d$ \\
\hline \multirow[t]{6}{*}{1} & \multirow{4}{*}{$\begin{array}{l}\text { Persetujuan warga berkaitan dengan } \\
\text { pencanangan Kampung Wisata Dusun } \\
\text { Santan. }\end{array}$} & RT 01 & 10 & 19 & 1 & 0 \\
\hline & & RT 02 & 9 & 26 & 0 & 0 \\
\hline & & RT 03 & 23 & 21 & 0 & 1 \\
\hline & & RT 04 & 7 & 19 & 0 & 1 \\
\hline & Jumlah & & 49 & 85 & 1 & 2 \\
\hline & $\%$ & & 36 & 62 & 0.6 & 1.4 \\
\hline \multirow[t]{6}{*}{2} & Perasaan senang atau tidak senang & RT 01 & 7 & 22 & 1 & 0 \\
\hline & warga berkaitan dengan Dusun Santan & RT 02 & 6 & 28 & 0 & 0 \\
\hline & yang resmi dijadikan sebagai & RT 03 & 19 & 26 & 0 & 0 \\
\hline & kampung wisata. & RT 04 & 7 & 20 & 0 & 0 \\
\hline & Jumlah & & 39 & 96 & 1 & 0 \\
\hline & $\%$ & & 28,4 & 71 & 0.6 & \\
\hline \multirow[t]{6}{*}{3} & \multirow{4}{*}{$\begin{array}{l}\text { Persetujuan warga mengenai perlunya } \\
\text { perencanaan Kampung Wisata Dusun } \\
\text { Santan sebaik-baiknya. }\end{array}$} & RT 01 & 7 & 23 & 0 & 0 \\
\hline & & RT 02 & 11 & 24 & 0 & 0 \\
\hline & & RT 03 & 20 & 25 & 0 & 0 \\
\hline & & RT 04 & 6 & 21 & 0 & 0 \\
\hline & Jumlah & & 44 & 93 & 0 & 0 \\
\hline & $\%$ & & 32 & 68 & 0 & 0 \\
\hline \multirow[t]{6}{*}{4} & Pendapat warga tentang dukungan & RT 01 & 10 & 20 & 0 & 0 \\
\hline & terhadap Kampung Wisata Dusun & RT 02 & 14 & 21 & 0 & 0 \\
\hline & Santan & RT 03 & 20 & 25 & 0 & 0 \\
\hline & & RT 04 & 6 & 21 & 0 & 0 \\
\hline & Jumlah & & 50 & 86 & 0 & 0 \\
\hline & $\%$ & & 36 & 74 & 0 & 0 \\
\hline
\end{tabular}

Keterangan Skor:

a. Sangat senang / mendukung b. Senang / Mendukung c. Kurang Senang / Mendukung d. Tidak senang / setuju sama sekali 
kegiatan pencanangan kampung wisata berada di RT 03, informasi bersumber dari RT 03 kemudian menyebar ke RT yang lain. Pencangan kampung wisata pada akhirnya diambil alih oleh pengurus kampung, sehingga melibatkan banyak elemen masyarakat mulai dari pengurus kampung, para pengrajin bathok, ibu-ibu PKK, kelompok kesenian dan lain sebagainya. Yang disayangkan masih banyak masyarakat yang hanya tahu secara sekilas atau sedikit tentang pencanangan Santan sebagai kampung wisata, yaitu anggota masyarakat yang kurang aktif, terutama yang jarak tempat tinggalnya cukup jauh dari pusat kegiatan peresmian tersebut.

Berdasarkan ketiga indikator sikap kognitif tersebut dapat disimpulkan bahwa informasi mengenai kampung wisata belum menyebar secara merata, yang dapat dilihat dari sebagian besar masyarakat Dusun Santan yang kurang tahu tentang kampung wisata, pencanangan kampung wisata sampai peresmian Kampung Wisata Santan. Warga yang mengetahui secara lengkap mengenai Kampung Wisata Santan adalah para tokoh masyarakat atau mereka yang berdomisili di lokasi pusat informasi atau pusat kegiatan kampung wisata. Masyarakat yang tinggal di lokasi lebih jauh memiliki informasi yang lebih sedikit dibandingkan dengan masyarakat yang berasal dari wilayah pusat informasi.

\section{SIKAP AFEKTIF MASYARAKAT TERHADAP PENCANANGAN KAMPUNG WISATA}

Sifat afektif dalam penelitian ini adalah perasaan atau emosi masyarakat terhadap pencanangan Kampung Wisata Santan. Walaupun masyarakat kurang mendapat informasi tentang pencanangan Dusun Santan sebagai kampung wisata, hampir semua masyarakat (100\%) mendukung bahkan sangat mendukung diresmikannya Kampung Wisata Santan (Tabel 2).

Berdasarkan Tabel 2 terlihat bahwa 62 persen masyarakat setuju dengan pencanangan kampung wisata Dusun Santan, sedangkan 36 persen yang lain sangat setuju, dan hanya 1 persen yang kurang setuju dan tidak setuju terhadap pencanangan kampung wisata Dusun Santan. Sebagian besar masyarakat Dusun Santan setuju dengan pencanangan Kampung Wisata Santan, karena masyarakat berharap pencanangan kampung wisata akan memberikan dampak yang positif bagi warga Dusun Santan. Masyarakat berharap Dusun Santan akan lebih maju dan mengangkat perekonomian masyarakat setempat. Akan tetapi diantara banyaknya masyarakat yang setuju, tetap terdapat satu dua orang yang tidak setuju terhadap pencanangan Kampung Wisata Santan. Warga yang tidak setuju memiliki persepsi bahwa dengan menjadi kampung wisata, Dusun Santan akan menjadi ramai dan kurang bersih. Masyarakat yang tidak setuju kebanyakan adalah pemuka agama yang merasa takut akan terjadi pergaulan bebas jika Dusun Santan menjadi kampung wisata.

Tabel 2 menunjukkan bahwa 70 persen masyarakat Dusun Santan senang dengan diresmikankanya Dusun Santan menjadi kampung wisata, bahkan ada 29 persen merasa sangat senang dengan pencanangan kampung wisata Dusun Santan; sedangkan yang kurang senang hanya 1 persen saja. Tidak ada satupun warga yang menolak atau tidak senang dengan adanya pencanangan kampung wisata Dusun Santan. Meskipun berdasarkan eksplorasi sebelumnya banyak warga yang belum tahu tentang pengertian kampung wisata, tetapi setelah mendapatkan gambaran pemahaman yang cukup, mereka setuju dan merasa sangat senang dengan pencanangan Dusun Santan sebagai kampung wisata. Masyarakat merasa senang karena dengan menjadi kampung wisata, Dusun Santan menjadi lebih maju dan masyarakatnya menjadi lebih produktif. Hanya satu orang yang merasa kurang senang, yaitu salah satu warga RT 01 dengan alasan bahwa masyarakat Dusun Santan dianggap masih kurang kompak sehingga belum siap untuk dijadikan kampung wisata.

Dari Tabel 2 dapat dilihat 68 persen masyarakat Dusun Santan setuju mengenai perlunya perencanaan kampung wisata yang sebaik-baiknya, sisanya 32 persen sangat setuju dengan hal tersebut. Dengan kata lain warga Dusun Santan setuju dan tidak ada yang kurang setuju atau tidak setuju dengan perlunya perencanaan kampung wisata yang sebaik-baiknya. Masyarakat Dusun Santan memiliki keinginan untuk membangun kampung wisata yang berhasil sehingga program-programnya pun harus direncanakan dengan sebaik-baiknya agar terkonsep dan tersusun dengan rapi. Selain dari pada itu masyarakat ingin agar pendapat masyarakat Dusun Santan dapat ditampung dan didiskusikan dengan baik agar menghasilkan program-program berkualitas sesuai dengan keinginan dan kebutuhan masyarakat.

Tabel 2 menunjukan bahwa 100 persen warga mendukung pogram Kampung Wisata. Masyarakat Dusun Santan memberikan dukungan terhadap program kampung wisata demi kemajuan Kampung Wisata Santan, masyarakat juga bangga bahwa lokasinya telah 
TABEL 3. DISTRIBUSI FREKUENSI PARTISIPASI MASYARAKAT DUSUN SANTAN

\begin{tabular}{|c|c|c|c|c|c|c|}
\hline \multirow{2}{*}{ No } & \multirow{2}{*}{ Komponen Partisipasi } & \multirow{2}{*}{ Domisili } & \multicolumn{4}{|c|}{ Jumlah } \\
\hline & & & $a$ & b & c & $d$ \\
\hline \multirow[t]{6}{*}{1} & \multirow{4}{*}{$\begin{array}{l}\text { Keterlibatan warga dalam rembug } \\
\text { perencanaan atau rembug tentang } \\
\text { Dusun Wisata. }\end{array}$} & RT 01 & 1 & 10 & 8 & 10 \\
\hline & & RT 02 & 0 & 8 & 14 & 13 \\
\hline & & RT 03 & 11 & 12 & 8 & 14 \\
\hline & & RT 04 & 1 & 9 & 4 & 13 \\
\hline & Jumlah & & 13 & 39 & 34 & 50 \\
\hline & $\%$ & & 9,6 & 28,7 & 25 & 36,7 \\
\hline \multirow[t]{6}{*}{2} & Keterlibatan warga dalam acara & RT 01 & 5 & 6 & 12 & 7 \\
\hline & peresmian atau pencanangan & RT 02 & 3 & 7 & 13 & 12 \\
\hline & Dusun Wisata Santan pada tahun & RT 03 & 11 & 14 & 8 & 12 \\
\hline & 2010 & RT 04 & 1 & 10 & 5 & 11 \\
\hline & Jumlah & & 20 & 37 & 38 & 42 \\
\hline & $\%$ & & 14 & 27 & 28 & 31 \\
\hline \multirow[t]{6}{*}{3} & & RT 01 & 4 & 12 & 13 & 1 \\
\hline & Partisipasi warga setelah program & RT 02 & 2 & 13 & 11 & 6 \\
\hline & telah berjalan & RT 03 & 21 & 16 & 4 & 4 \\
\hline & & RT 04 & 3 & 9 & 12 & 3 \\
\hline & Jumlah & & 30 & 50 & 40 & 14 \\
\hline & $\%$ & & 22 & 37 & 30 & 11 \\
\hline
\end{tabular}

Keterangan skor:

a. Terlibat secara penuh; b. Terlibat sebagian besar; c. Terlibat sebagian kecil; d. Tidak terlibat

mengalami kemajuan dengan menjadi sebuah kampung wisata. Masyarakat berharap jika Kampung Wisata Santan maju, maka usaha masyarakatnya pun akan ikut maju sehingga perekonomian masyarakat setempat akan naik.

Berdasarkan keempat komponen sikap afektif masyarakat Dusun Santan mengenai pencanangan kampung wisata Dusun Santan dapat disimpulkan bahwa sebagian besar warga senang dan setuju terhadap dicanangkannya Dusun Santan sebagai kampung wisata. Masyarakat merasa bahwa daerahnya berubah menjadi lebih baik setelah dusun santan diresmikan menjadi kampung wisata, baik dilihat dari segi ekonomi maupun sosial. Pasca tragedi gempa bumi besar yang melanda Kabupaten Bantul pada tahun 2006 banyak masyarakat yang terpuruk dan menjadi malas bekerja, hal tersebut berangsur menjadi lebih baik setelah Dusun Santan dicanangkan menjadi kampong wisata. Masyarakat Santan cenderung menjadi lebih semangat bekerja dan aktif dalam berbagai kegiatan sosial. Masyarakat Dusun Santan juga memikirkan akan keberhasilan kampung wisata di daerahnya, hal tersebut terbukti dengan banyaknya masyarakat yang setuju dengan perlunya perencanaan kampung wisata Dusun Santan yang sebaik- baiknya.

\section{PARTISIPASI MASYARAKAT}

Partisipasi dalam penelitian ini adalah kecenderungan tindakan atau keterlibatan masyarakat dalam pencanangan kampung wisata. Walaupun tidak banyak masyarakat yang terlibat secara penuh dalam pencanangan Dusun Santan sebagai kampung wisata, namun nampak adanya peningkatan keterlibatan seiring berjalannya program. Jika pada kegiatan perencanaan kurang dari $10 \%$ warga yang terlibat penuh, pada acara peresmian warga yang terlibat penuh meningkat menjadi $14 \%$, dan menjadi 20\% setelah program berjalan (Tabel 3).

Tabel 3 menunjukkan bahwa sebagian besar (36,7\%) masyarakat tidak terlibat dalam musyawarah Kampung Wisata Dusun Santan, 25 persen masyarakat terlibat sedikit dalam musyawarah. Hanya 9,6 persen warga yang secara penuh dan yang terlibat sebagian besar hanya $28,7 \%$. Sebagian besar ketidak ikut sertaan masyarakat Dusun Santan disebabkan karena sikap kognitif masyarakat yang rendah, masyarakat tidak tahu mengenai adanyanya musyawarah kampung wisata, sehingga masyarakat banyak yang tidak terlibat karena merasa tidak 
diundang dalam musyawarah. Sebagian yang lain mengetahui adanya musyawarah kampung wisata, tetapi memiliki kegiatan lain yang harus dilakukan sehingga tidak dapat turut andil dalam kegiatan musyawarah.

Masyarakat yang paling banyak terlibat dalam musyawarah adalah masyarakat yang berasal dari RT 03. Hal tersebut disebabkan karena RT 03 adalah pusat informasi dan kegiatan, sehingga sikap kognitif masyarakat RT 03 cenderung lebih tinggi dari RT yang lain, yang akhirnya berdampak pada keterlibatan dalam musyawarah kampung wisata. Masyarakat RT 04 banyak yang tidak terlibat dalam musyawarah karena lokasinya yang paling jauh dari pusat informasi dan kegiatan.

Keterlibatan warga dalam peresmian Kampung Wisata Dusun Santan berdasarkan Tabel 3 menunjukan bahwa 31 persen masyarakat tidak terlibat dalam peresmian kampung wisata, 28 persen hanya mengikuti sebagian kecil, sedangkan yang terlibat sebagian besar hanya 27 persen dan yang terlibat secara penuh hanya 14 persen saja. J ika dilihat dari tabel distribusi frekuensi partisipasi masyarakat, maka akan terlihat bahwa masyarakat RT 03 mendominasi masyarakat yang terlibat dalam peresmian. Hal tersebut karena lokasi RT 03 menjadi pusat informasi dan kegiatan, sehingga masyarakat yang berada di RT 03 memiliki informasi lebih banyak mengenai acara peresmian kampung wisata. Masyarakat yang memiliki lokasi rumah lebih jauh akan lebih sedikit menerima informasi dan lebih segan untuk datang dibandingkan dengan masyarakat yang memiliki rumah dekat dengan lokasi informasi dan kegiatan.

Tabel 3 menunjukkan bahwa 37 persen masyarakat terlibat sebagian besar, sedangkan 30 persen masyarakat hanya terlibat sebagian kecil, kemudian 22 persen terlibat secara penuh dan 11 persen tidak terlibat sama sekali pada program Kampung Wisata setelah pencanangan. Berdasarkan dari ketiga komponen dapat disimpulkan bahwa masyarakat Dusun Santan kurang terlibat dalam pencanangan kampung wisata Dusun Santan, baik ketika musyawarah untuk pencanangan maupun ketika peresmian kampung wisata itu sendiri. Meskipun demikian, setelah program kampung wisata telah dilaksanakan masyarakat cukup banyak yang terlibat sebagian besar, begitu pula yang terlibat secara lengkap juga terbilang cukup banyak. Hanya sedikit masyarakat yang tidak terlibat sama sekali.

Pemahaman kampung wisata yang kurang dapat menyebabkan masyarakat menjadi takut dan berpikiran buruk, sehingga banyak masyarakat yang tidak senang atau tidak setuju terhadap program kampung wisata. Akan tetapi setelah program telah berjalan masyarakat mulai merasakan manfaat dari kampung wisata, sehingga masyarakat yang tadinya tidak senang atau tidak setuju dengan kampung wisata menjadi senang dan turut berpartisipasi.

TABEL 4. DISTRIBUSI FREKUENSI PROGRAM KAMPUNG WISATA YANG PALING DIMINATI

\begin{tabular}{llll}
\hline No. & $\begin{array}{l}\text { Aktifitas yang } \\
\text { Diminati }\end{array}$ & $\begin{array}{l}\text { Distribusi } \\
\text { Frekuensi }\end{array}$ & $\%$ \\
\hline 1 & Kesenian & 18 & 14 \\
2 & Kuliner & 22 & 16 \\
3 & Kerajinan & 30 & 22 \\
4 & Pertanian & 9 & 7 \\
5 & Sarana Wisata & 55 & 41 \\
\hline
\end{tabular}

Tabel 4 menjelaskan bahwa 41 persen masyarakat lebih berminat berpartisipasi pada sarana wisata. Partisipasi dalam sarana wisata tersebut meliputi pengadaan homestay bagi para pengunjung wisata. Kemudian minat yang selanjutnya adalah kerajinan yang tidak lain adalah kerajinan bathok kelapa yaitu sebesar 22 persen, disusul dengan kuliner 16 persen dan pertanian 7 persen. Banyaknya peminat terhadap sarana wisata dikarenakan masyarakat dapat memanfaatkan rumah pribadinya sebagai homestay, disaat ada pengunjung yang menginap di Kampung Wisata Santan, sehingga dapat dijadikan sebagai pemasukan tambahan bagi keluarga di samping pekerjaan utama. Masyarakat yang memilih kerajinan bathok kelapa adalah para perajin bathok kelapa, karena memang pekerjaan itulah yang menjadi pekerjaan pokok masyarakat tersebut. Presentase minat yang paling kecil adalah terhadap pertanian, hal tersebut dikarenakan masyarakat yang masih menjadi petani murni memang sudah tidak banyak.

\section{HARAPAN MASYARAKAT}

Harapan masyarakat pada penelitian ini adalah sesuatu yang ingin dicapai oleh masyarakat dengan adanya pencanangan kampung wisata. Dalam hal ini harapan masyarakat dikelompokan menjadi tiga yang digambarkan dalam sebuah diagram ven (Gambar 2). 
Masyarakat memiliki harapan bahwa dengan peresmian kampung wisata akan menimbulkan manfaat bagi penduduk Dusun Santan. Berdasarkan data yang tertera pada Gambar 2 dapat dilihat berbagai macam variasi pendapat masyarakat mengenai sumber keuntungan yang akan didapat dari pengunjung kampung wisata Dusun Santan. Sebagian besar (63\%) masyarakat memiliki harapan bahwa setiap orang yang datang untuk menikmati keindahan, kerajinan bathok, dan kebudayaan, akan menginap satu malam. Sementara 23 persen masyarakat lainnya memiliki harapan, bahwa setiap orang yang datang untuk menikmati keindahan, kerajinan, dan kebudayaan kemudian pulang. Terdapat 14 persen warga yang memiliki harapan, bahwa setiap orang yang datang hanya menikmati keindahan alam dan lokasi wisata kemudian langsung pulang.

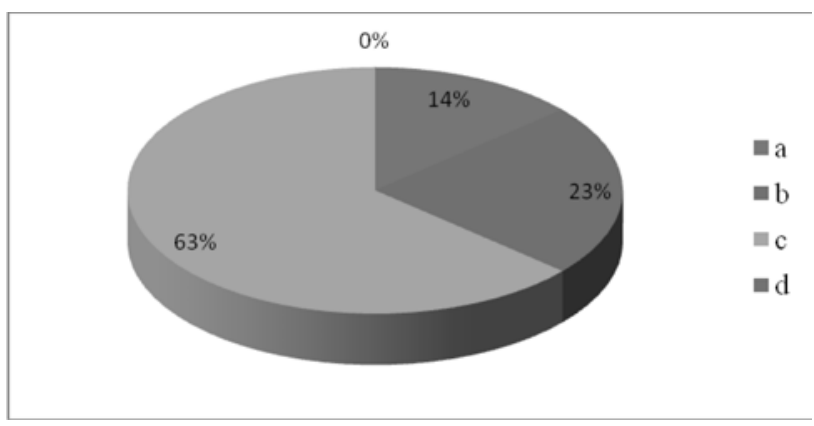

\section{GAMBAR 2. DIAGRAM VEN PERSENTASE HARAPAN WARGA TERHADAP PENGUNJUNG KAMPUNG WISATA SANTAN}

Keterangan :

a. Orang datang menikmati keindahan alam dan lokasi wisata kemudian langsung pulang

b. Orang datang menikmati keindahan alam, kerajinan bathok, dan kebudayaan kemudian pulang

c. Orang datang menikmati keindahan, kerajinan bathok, dan kebudayaan dengan menginap 1 malam kemudian pulang

d. Orang datang menikmati keindahan alam, kerajinan bathok,kebudayaan dan kalau bisa terlibat dalam kegiatan masyarakat yang khas (unik) menginap lebih dari 1 malam

Merujuk kepada Gambar 3, sebagian besar (73\%) masyarakat mengatakan bahwa tarif biaya berwisata ke Dusun Santan perlu dilakukan, sedangkan 27 persen yang lain mengatakan tidak perlu menetapkan tarif biaya berwisata. Dengan adanya pencanangan kampung wisata santan masyarakat tetap menginginkan timbal balik dari usaha yang telah dilakukan, pendapatan yang didapatkan dari kampung wisata diharapkan dapat kembali kepada masyarakat Dusun Santan.

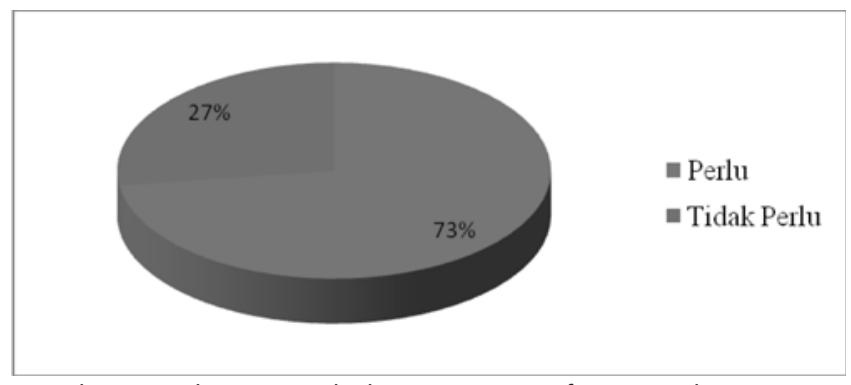

Gambar 3. Pendapat Warga berkaitan Dengan Tarif Berwisata ke Kampung Wisata Santan

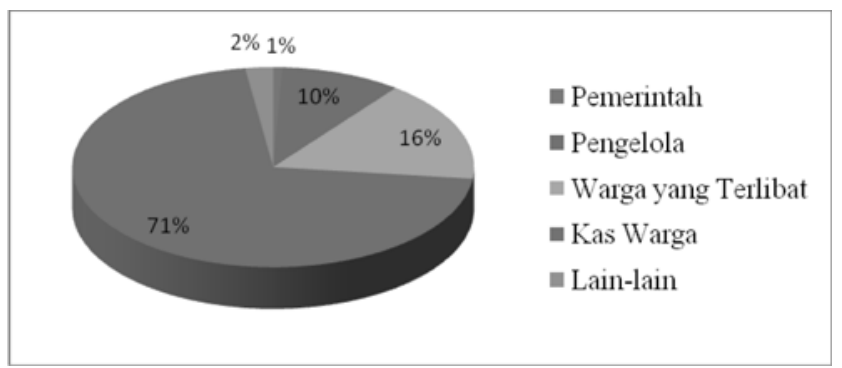

\section{GAMBAR 4. HARAPAN MASYARAKAT TENTANG HAK PENDAPATAN KAMPUNG WISATA}

Gambar 4 menunjukkan bahwa 71 persen masyarakat memiliki harapan bahwa hasil dari pendapatan kampung wisata adalah untuk kas warga, 16 persen yang lain berpendapat hasil dari kampung wisata sebaiknya untuk warga yang terlibat saja, sedangkan 10 persen masyarakat yang lain lagi mengatakan bahwa hasil dari kampung wisata adalah untuk pengelola. Berdasarkan hasil penelitian tersebut dapat disimpulkan bahwa masyarakat menginginkan keuntungan dari kampung wisata digunakan untuk kesejahteraan masyarakat Dusun Santan sendiri guna memperbaiki infrastruktur yang nantinya akan digunakan oleh warga setempat.

\section{HUBUNGAN FAKTOR LINGKUNGAN FISIK, SOSIAL DAN RESPON MASYARAKAT}

Dalam penelitian ini diteliti juga bagaimana hubungan faktor lingkungan fisik dan faktor lingkungan sosial terhadap respon masyarakat Dusun Santan. Faktor lingkungan fisik dilihat dari jarak domisili rumah masyarakat dengan lokasi pusat kegiatan dan informasi. 
TABEL 5. HUBUNGAN FAKTOR LINGKUNGAN FISIK DAN RESPON MASYARAKAT DUSUN SANTAN

\begin{tabular}{llllllll}
\hline No & Domisili & $\begin{array}{l}\text { Skor } \\
\text { Jarak }\end{array}$ & $\begin{array}{l}\text { Jumlah } \\
\text { Penduduk }\end{array}$ & Kognitif & Afektif & Partisipasi & $\begin{array}{l}\text { Rotala } \\
\text { Respon } \\
\text { (K,A,P) }\end{array}$ \\
\hline 1 & RT 01 & 2 & 30 & 2,7 & 3,3 & 1,8 & 7,8 \\
2 & RT 02 & 2 & 35 & 2,2 & 3,2 & 2,0 & 7,4 \\
3 & RT 03 & 1 & 45 & 2,6 & 3,4 & 2,7 & 8,7 \\
4 & RT 04 & 3 & 28 & 2,1 & 3,1 & 2,1 & 7,3 \\
\hline
\end{tabular}

Pusat kegiatan terletak pada RT 03, sehingga rumah warga yang berada di RT 03 memiliki jarak paling dekat dengan pusat informasi dan kegiatan. Lokasi RT 03 berada di antara RT 01dan RT 02 sehingga lokasi yang paling jauh adalah RT 04. Hubungan faktor lingkungan fisik terhadap respon masyarakat Dusun Santan dapat dilihat pada Tabel 5.

Berdasarkan Tabel 5 terlihat berbagai macam variasi jumlah skor respon sesuai dengan rumah warga berdasarkan rukun tetangga (RT). Jumlah rata-rata sikap kognitif berkisar antara 1 sampai dengan 4 , begitu pula dengan sikap afektif dan partisipasi. Berdasarkan jumlah rata-rata skor respon, diperoleh total respon yang terdiri dari jumlah skor sikap kognitif, afektif, dan partisipasi. Jumlah total skor respon masyarakat yang tertinggi terdapat pada RT 03, yaitu berjumlah 8,7; diikuti dengan jumlah skor respon RT 01 berjumlah 7,8; kemudian jumlah skor respon RT 02 berjumlah 7,4; dan yang terakhir sekaligus yang terjauh adalah jumlah respon RT 04 yaitu berjumlah 7,3.

Berdasarkan data tersebut, dilakukan pula analisis korelasi rank spearman untuk mengetahui korelasi antara faktor lingkungan fisik dan respon masyarakat. Hasil korelasi dapat dilihat pada Tabel 6 .

TABEL 6. KORELASI PENGARUH FAKTOR LINGKUNGAN FISIK DAN RESPON MASYARAKAT DUSUN

\begin{tabular}{|c|c|c|c|c|c|}
\hline & & Jarak & Kognitif & Afektif & Partisipasi \\
\hline \multirow[t]{3}{*}{ Jarak } & $\begin{array}{l}\text { Correlation } \\
\text { Coefficient }\end{array}$ & 1,000 & $-0,200(*)$ & $-0,224(* *)$ & $-0,299\left(^{* *}\right)$ \\
\hline & Sig. (2-tailed) & . & 0,019 & 0,008 & 0,000 \\
\hline & N & 138 & 138 & 138 & 138 \\
\hline
\end{tabular}

Hasil korelasi menunjukkan bahwa terdapat hubungan (korelasi) antara jarak domisili warga dengan respon masyarakat dalam hal ini sikap kognitif, afektif dan partisipasi. Korelasi antara jarak domisili warga dengan sikap kognitif adalah negatif, demikian juga korelasi antara jarak domisili warga dengan sikap afektif dan partisipasinya.

Secara parsial dapat dinyatakan bahwa korelasi jarak domisili warga dengan sikap kognitif menunjukan nilai koefisien korelasi -0,200. Artinya bahwa makin jauh jarak (skor semakin besar) maka sikap kognitifnya semakin rendah atau sebaliknya. Dalam hal ini makin jauh jarak domisili warga dengan pusat kegiatan kampung wisata maka pengetahuan warga terhadap kampung wisata semakin rendah atau semakin kecil. Hasil yang kedua menyatakan bahwa korelasi jarak domisili warga dengan sikap afektif menunjukan nilai koefisien korelasi -0,224. Artinya bahwa makin jauh jarak (skor semakin besar) maka sikap afektif semakin rendah atau sebaliknya. Dalam hal ini makin jauh jarak domisili warga dengan pusat kegiatan kampung wisata maka perasaan senang atau persetujuan warga terhadap warga terhadap kampung wisata semakin rendah atau semakin kecil. Hasil analisis data yang ketiga menyatakan bahwa ada hubungan yang rendah antara jarak dengan partisipasi. Hasil uji korelasi menunjukan nilai koefisien korelasi -0,299. Berdasarkan hasil analisis korelasi tersebut menunjukkan terdapat hubungan negatif yang signifikan antara jarak dan partisipasi.

Berdasarkan penelitian yang telah dilakukan dapat disimpulkan bahwa jarak antara rumah warga dengan pusat informasi dan kegiatan desa wisata memiliki hubungan yang signifikan dengan arah korelasi negatif dengan keseluruhan respon masyarakat terhadap pencanangan kampung wisata Dusun Santan.

Keseluruhan respon yang dimaksud adalah sikap kognitif, afektif dan partisipasi. Berdasarkan arah korelasi yang 
TABEL 7. PENGARUH FAKTOR LINGKUNGAN SOSIAL TERHADAP RESPON MASYARAKAT DUSUN SANTAN

\begin{tabular}{llllllll}
\hline No & Domisili & $\begin{array}{l}\text { Skor } \\
\text { kompak }\end{array}$ & $\begin{array}{l}\text { Jumlah } \\
\text { Penduduk }\end{array}$ & $\begin{array}{l}\text { Rata-rata } \\
\text { Kognitif (K) }\end{array}$ & Afektif (A) & Partisipasi (P) & $\begin{array}{l}\text { Total } \\
\text { Respon } \\
\text { (K,A.P) }\end{array}$ \\
\hline 1 & RT 01 & 3 & 30 & 2,7 & 3,3 & 1,8 & 7,8 \\
2 & RT 02 & 2 & 35 & 2,2 & 3,2 & 2,0 & 7,4 \\
3 & RT 03 & 4 & 45 & 2,6 & 3,4 & 2,7 & 8,7 \\
4 & RT 04 & 1 & 28 & 2,1 & 3,1 & 2,1 & 7,3 \\
\hline
\end{tabular}

TABEL 8. HASIL KORELASI FAKTOR LINGKUNGAN SOSIAL DAN RESPON MASYARAKAT

\begin{tabular}{llllll}
\hline \multirow{2}{*}{ Kekompakan } & $\begin{array}{l}\text { Correlation } \\
\text { Coefficient }\end{array}$ & $\begin{array}{l}\text { Kekompakan } \\
1,000\end{array}$ & $\begin{array}{l}\text { Kognitif } \\
0,239\left({ }^{*}\right)\end{array}$ & $\begin{array}{l}\text { Afektif } \\
0,215\left({ }^{*}\right)\end{array}$ & $\begin{array}{l}\text { Partisipasi } \\
0,257\left({ }^{*}\right)\end{array}$ \\
\hline Sig. (2-tailed) & & 0,005 & 0,011 & 0,002 \\
$N$ & 138 & 138 & 138 & 138 \\
\hline \multicolumn{5}{c}{${ }^{*}$ Terdapat korelasi lemah tapi pasti }
\end{tabular}

negatif dapat dijelaskan bahwa semakin dekat rumah warga dengan pusat informasi dan kegiatan kampung wisata maka sikap kognitif, sikap afektif dan partisipasi warga semakin tinggi. Hal ini disebabkan karena masyarakat pedesaan masih menggunakan model komunikasi interpersonal, dalam model ini masyarakat memperoleh informasi secara langsung dari sumbernya dengan cara melihat, mendengar, atau merasakan sendiri secara lansung kejadian atau peristiwa yang menjadi pesan komunikasi. Informasi yang didapat akan mempengaruhi pengetahuannya kemudian pengetahuan akan mempengaruhi sikap dan pada akhirnya akan mempengaruhi tindakan dalam hal ini adalah partisipasi.

Berbagai informasi yang kemungkinan didapat oleh warga berupa berbagai hal, mulai dari pengetahuan mengenai definisi kampung wisata, pengetahuan mengenai perencanaan pencanangan kampung wisata, pengetahuan mengenai peresmian kampung wisata sampai dengan informasi tentang program-program kampung wisata. Meskipun sosialisasi telah dilakukan terhadap seluruh warga melalui pertemuan-pertemuan, namun mayoritas warga akan lebih memahami, merasakan dan timbul motivasi untuk berpartisipasi jika warga mengetahui atau mendapatkan informasi secara langsung.

Pengetahuan yang diperoleh masyarakat berdampak pada sikap afektif dan partisipasi masyarakat. Semakin besar informasi yang diperoleh masyarakat, maka menimbulkan perasaan senang dan persetujuan yang semakin besar pula didalam diri para warga kampung Dusun Santan. Masyarakat yang memahami makna kampung wisata akan mengetahui manfaat-manfaat yang akan ditimbulkan dengan adanya pencanangan kampung wisata. Masyarakat akan memiliki pemikiran yang semakin maju seiring dengan adanya program kampung wisata dan memiliki keinginan untuk memperbaiki ekonomi keluarganya kearah yang semakin baik dari sebelumnya. Pemikiran tersebut akhirnya memancing masyarakat untuk berpartisipasi dalam program Kampung Wisata Santan.

Pada penelitian ini faktor lingkungan sosial dapat dilihat dari kekompakan masyarakat berdasarkan pandangan para tokoh dengan partisipasi pada kenyataannya. Lokasi yang dinilai paling kompak adalah RT 03, kemudian diikuti oleh RT 01, RT 02, dan yang terakhir adalah RT 04. Faktor lingkungan sosial dapat digambarkan pada Tabel 7.

Berdasarkan Tabel 7 terlihat jumlah skor respon sesuai dengan kekompakan masyarakat di tingkat RT menurut penilaian para tokoh. Jumlah rata-rata sikap kognitif berkisar antara 1 sampai dengan 4 , begitu pula dengan sikap afektif dan partisipasi. Semakin mendekati 
angka 1 maka respon yang ditunjukan semakin kecil, begitu pula sebaliknya, semakin mendekati angka 4 maka semakin tinggi respon yang ditunjukan. Total respon adalah jumlah dari rata-rata skor sikap kognitif, sikap afektif dan partisipasi. Jika ditarik kesimpulan secara garis besar berdasarkan tabel di atas, lokasi yang dinilai memiliki kekompakan paling tinggi adalah RT 03 memiliki total jumlah skor respon yang paling tinggi juga yaitu 8,7; kemudian diikuti oleh lokasi yang dinilai paling kompak selanjutnya RT 01 yaitu sebesar 7,8; dilanjutkan oleh RT 02 yaitu sebesar 7,4 dan yang terakhir RT 01 dengan penilaian kekompakan paling rendah yaitu 7,3.

Hasil korelasi menunjukkan bahwa terdapat hubungan (korelasi) antara kekompakan warga dengan respon masyarakat dalam hal ini sikap kognitif, afektif dan partisipasi. Korelasi antara kekompakan warga dengan sikap kognitif adalah positif, demikian juga korelasi antara kekompakan warga dengan sikap afektif dan partisipasinya.

Secara parsial dapat dinyatakan bahwa korelasi kekompakan warga dengan sikap kognitif menunjukan nilai koefisien korelasi 0,239 Artinya bahwa semakin kompak (skor semakin besar) maka sikap kognitifnya semakin tinggi atau sebaliknya. Dalam hal ini semakin kompak warga dalam sebuah RT maka pengetahuan warga terhadap kampung wisata semakin tinggi. Hasil yang kedua menyatakan bahwa korelasi kekompakan warga dengan sikap afektif menunjukan nilai koefisien korelasi 0,215 bernilai positif. Artinya bahwa semakin kompak (skor semakin besar) maka sikap afektifnya semakin tinggi atau sebaliknya. Dalam hal ini semakin kompak warga dalam sebuah RT maka perasaan senang atau persetujuan warga terhadap kampung wisata semakin tinggi.

Hasil analisis data yang ketiga menyatakan bahwa ada hubungan yang rendah antara kekompakan warga dengan partisipasi. Hasil uji korelasi menunjukkan nilai koefisien korelasi 0,257. Hasil analisis korelasi tersebut menunjukkan terdapat hubungan positif yang signifikan antara kekompakan warga dan partisipasi. Berdasarkan analisis tersebut dapat disimpulkan bahwa kekompakan masyarakat dapat mempengaruhi penyebaran informasi diantara masyarakat Dusun Santan. Lokasi yang dinilai memiliki kekompakan lebih tinggi di bandingkan lokasi lain memungkinkan masyarakatnya lebih sering bertemu dan bertegur sapa sehingga informasi akan lebih cepat menyebar luas. Masyarakat pedesaan cenderung masih menggunakan sistem komunikasi interpersonal saja, sehingga informasi yang didapat adalah dengan cara saling bertemu dan berbicara secara langsung. Pengetahuan dan pemahaman masyarakat yang kompak akan kampung wisata akan lebih matang dibandingkan dengan lokasi yang kurang kompak.

Dengan adanya kekompakan maka akan timbul kebersamaan, sehingga dengan adanya kebersamaan yang terjalin dapat menimbulkan rasa senang di kalangan masyarakat. Masyarakat yang lebih kompak akan senang terhadap program dan agenda kampung wisata Dusun Santan dibanding dengan masyarakat yang kurang kompak. Jika rasa senang dan persetujuan telah muncul, maka masyarakat akan lebih mudah untuk berpartisipasi tanpa adanya paksaan. Rasa senang dan rasa segan yang muncul diantara individu akan mendorong masyarakan untuk lebih aktif dan simpati diantara sesama, selain dari pada itu rasa nyaman terhadap sesama akan menimbulkan sikap tenggang rasa dan toleransi diantara satu warga dengan warga yang lainnya.

\section{KESIMPULAN}

Predisposisi atau kesiapan masyarakat dalam perencanaan kampung wisata ditunjukkan oleh pemahaman, sikap dan partisipasi masyarakat mulai dari perencanaan (persiapan), pencanangan (peresmian) maupun pasca pencanangan kampung wisata. Secara umum pemahaman kognitif masyarakat terhadap pengertian kampung wisata, pengetahuan akan perencanaan dan pencanangan Dusun Santan sebagai kampung wisata sebagian besar masih kurang (hanya tahu sedikit). Hal ini karena kendala sosialisasi dan dominasi para tokoh kampung dalam perencanaan kampung wisata yang kurang melibatkan warga kampung secara merata. Sikap afektif masyarakat terhadap pencanangan kampung wisata Santan menunjukkan kecenderungan persetujuan, rasa senang dan mendukung. Setelah masyarakat mendapatkan sosialisasi meskipun masih sangat terbatas, respon afektifnya sangat positif dan mendukung program kampung wisata. Masyarakat berharap agar Dusun Santan bisa lebih maju dan meningkat perekonomiannya.

Partisipasi masyarakat pada program kampung wisata menunjukkan gejala yang meningkat, mulai dari partisipasi sejak perencanaan, pada saat pencanangan dan pada saat pasca pencanangan. Bentuk partisipasi dapat dilihat dari jumlah keterlibatan diri masyarakat dan rencana program yang paling diminati. Program kampung wisata yang paling diminati masyarakat adalah 
penyediaan sarana prasarana, karena program ini diharapkan mendatangkan keuntungan langsung pada pelaksana. Terdapat hubungan yang signifikan antara domisili dan kekompakan warga dengan respon masyarakat terhadap program kampung wisata.

Sosialisasi tentang program kampung wisata perlu terus dilakukan misalnya dengan penyebaran brosur, menempel pamflet atau secara langsung dalam forum-forum pertemuan masyarakat seperti pertemuan RT, atau pertemuan ibu PKK. Peningkatan volume sosialisasi diyakini dapat meningkatkan pemahaman, sikap dan partisipasi masyarakat dalam program kampung wisata. Predisiposisi (kesiapan) masyarakat dalam perencanaan kampung wisata menunjukan gejala yang positif dapat dimanfaatkan sebagai modal sosial masyarakat dalam perencanaan program kampung wisata Dusun Santan dimasa yang akan datang. Kekompakan warga perlu ditingkatkan, terutama peningkatan peran para tokoh dalam mendorong partisipasi warga, misalnya dalam bentuk gerakan gotong royong.

\section{DAFTAR PUSTAKA}

Awang, S.A.; H. Santoso; W.T. Widayati; Y. Nugroho; Kustomo; Sapardiono. 2001. Gurat hutan rakyat di kapur selatan. Yogyakarta: Debut Press.

Blackstock, K. 2005. A critical look at community base tourism. Community Development Journal 40(1): 39 - 49.

Echtner, C. M. 2002. The content of the third world tourism marketing: a 4A Approach. International Journal of Tourism Research 4: 413-434.

Damanik, J. \& H. F. Weber. 2006. Perencanaan Kampung Wisata: Dari Teori ke Aplikasi. Yogyakarta: Pusat Studi Pariwisata dan Penerbit Andi.

Gartner, W. C. 2004. Rural tourism development in the USA. International Journal of Tourism Research 6: 151 164.

Lansing, P., and P. De Vries. 2007. Sustainable tourism: ethical alternative or marketing ploy?. Journal of Business Ethics 72:77-85.

Nugroho, I. (2011). Ekowisata dan Pembangunan Berkelanjutan. Yogyakarta: Pustaka Pelajar.

Pike, S. 2005. Tourism destination branding complexity. The Journal of Product and Brand Management 14(4): 258 $-259$.

Pinel, D. P. 1998. Create A Good Fit: A Community-
Based Tourism Planning Model. Pinel E Association Research $\mathcal{E}$ Planning, Canada.

Santosa, S. P. 2002. Pengembangan Pariwisata Indonesia. www.google.com. Diunduh pada tanggal 20 Mei 2009.

Simon, H. 1999. Pengelolaan Hutan Bersama Rakyat (Cooperative Forest Management). Teori dan Aplikasi pada Hutan Jati di Jawa. Yogyakarta: Bigraf Publishing.

Welford, R. dan B. Ytterhus. 2004. Suistainable development and tourism destination management: A case study of the Lillahammer region, Norwey. International Journal of Sustainable Development and World Ecology, 11:410 - 422 . 